\title{
POSITION OF MICRO AND SMALL ENTERPRISES LIMITED LIABILITY COMPANY REVIEWED FROM LAW NUMBER 11 OF 2020 CONCERNING WORK CREATION
}

\author{
Baiq Mely Candra; Zainal Asikin; L. Wira Pria S. \\ Graduate Program in Notary, Faculty of Law, University of Mataram, Indonesia \\ email: baiqmeli123@gmail.com
}

\begin{abstract}
This study aims to determine the position of Micro and Small Enterprises Limited Liability Company as regulated in Law Number 11 of 2020 concerning of Job Creation, as well as the way of its establishment and the form of responsibility for the founders of Micro and Small Enterprises Limited Liability Company. This research is a type of normative legal research using a statutory approach method and a conceptual approach. From the results of the study it is concluded that first, the position of Micro and Small Enterprises Limited Liability Company is as an individual legal entity where this Limited Liability Company must reach the criteria for micro and small businesses as stipulated in Government Regulation Number 7 of 2021. Second, the method of establishing Micro and Small Enterprises Limited Liability Company, to Private Company was established based on the provisions of the Job Creation Law and Government Regulation Number 8 of 2021, while for the Company it was established based on the provisions of Law Number 40 of 2008 concerning Limited Liability Companies. Third, the form of responsibility of the founder of Micro and Small Enterprises Limited Liability Company, both before and after being legalized as a legal entity, is the same as the form of responsibility of the Limited Liability Company in general.
\end{abstract}

Keywords: Position, Micro and Small Enterprises Limited Liability Company

DOI: $10.7176 / \mathrm{JLPG} / 108-10$

Publication date: April $30^{\text {th }} 2021$

\section{Introduction}

Limited Liability Companies (LLC) are one of the most preferred and preferred business entities by business actors compared to other legal entities, because functionally LLC can be used as a means to support and carry out activities of the national economy without being limited to business actors. LLC is a capital alliance divided into several stock, so that the establishment of the Company as a legal entity is contractual, namely the establishment of the company as a result of the agreement. In the provisions of Article 1 number (1) of Law Number 40 of 2007 concerning Limited Liability Companies, it is stated that Limited Liability Companies, referred as Companies, are legal entities which are capital partnerships, established based on an agreement, conducting business activities with authorized capital which is entirely divided into shares and fulfills the requirements stipulated in this law and its implementing regulations.

Thus it can be observed that the establishment of a LLC is based on the existence of legal actions committed by business actors who bind themselves to one another. As stated in the article previously described, a company as a legal entity is established based on an agreement, wherein the company founder which is a capital alliance between the founders and / or shareholders must comply with the agreement law stipulated in Book Three of the Civil Code Article 1313-1341. The requirements for the establishment of a LLC are regulated in Article 7 paragraph (1) of Law Number 40 of 2007, namely that the Company is established by 2 (two) or more persons with a notary deed drawn up in Indonesian.

Currently the government has issued a new Law, namely Law Number 11 of 2020 concerning work copyrights which in the fifth section regulates Limited Liability Companies. Article 109 regulates several amendments to the provisions of Law Number 40 of 2007 concerning Limited Liability Companies, namely in Article 1 defines a Limited Liability Company, hereinafter referred to as a Company, is a legal entity which is a capital partnership, established based on an agreement, carrying out business activities with an entirely authorized capital. divided into shares or individual legal entities that reach the criteria for Micro and Small Enterprises as stipulated in the statutory regulation concerning Micro and Small Enterprises. This means that the scope of a Limited Liability Company is not only in the form of a capital partnership, but also includes individual businesses that reach the criteria of micro and small businesses.

Furthermore, in Article 153A of the Job Creation Law regulates that Companies that meet the criteria 
for Micro and Small Enterprises can be established by 1 (one) person. The provisions of the Article indicate that a Micro and Small Business Limited Liability Company can be established by one people or more, but it is possible that Micro and Small Enterprises Limited Liability Company will be established by one person whose shareholders are fully owned by one person. The problem is that when Micro and Small Enterprises Limited Liability Company is founded by one person, the provisions and regulations will be different, for example at the GMS which is one of the activities of LLC. If the shareholder is one person, the GMS cannot be held, the Micro and Small Enterprises which were in the form of a LLC are not appropriate because they are not in accordance with the rules stipulated in the LLC Law.

Furthermore, Article 153A of the Job Creation Law regulates that Companies that meet the criteria for Micro and Small Enterprises can be established by 1 (one) person. The provisions of the Article indicate that a Micro and Small Enterprises Limited Liability Company can be established by one person or more, but it is possible that Micro and Small Enterprises Limited Liability Company later will be established by one person whose shareholders are fully owned by one person. The problem is that when Micro and Small Enterprises Limited Liability Company is founded by one person, the provisions and regulations will be different, for example at the GMS which is one of the activities of LLC. If the shareholder is one person, the GMS cannot be held then the Micro and Small Enterprises which were in the form of a LLC are not appropriate because they are not in accordance with the rules stipulated in the Law on LLC.

This situation will create a conflict of norms between Article 153A of Law Number 11 of 2020 and Article 7 paragraph (1) of Law Number 40 of 2007 concerning Limited Liability Companies regarding the establishment of LLC as a legal entity. Based on this, researchers are interested in analyzing the position of Micro and Small Enterprises Limited Liability Company in terms of Law Number 11 of 2020 concerning Job Creation. So that later solutions can be found to solve these problems.

\section{Research Methods}

This research is a type of normative legal research, using a statute approach and conceptual approach. Sources of legal materials used in this research are primary legal materials such as statutory regulations, secondary legal materials such as general books, legal journals, doctrines, legal research results, legal dictionaries, and legal encyclopedias. Tertiary legal materials such as general dictionaries, magazines, as well as materials outside the field of law that are relevant and can be used to supplement data. The technique of collecting law materials is by library research or literature study through the steps of identifying law materials, classification of law materials, and specifications of law materials that have been collected and selected $/$ classified to make it easier for researchers to analyze the problems under study. Analysis of law materials is carried out by interpreting the law materials that have been processed, and the conclusion of this research is using the deductive method.

\section{Result and disscusion}

A. Position of Micro and Small Enterprises Limited Liability Company in terms of Law Number 11 of 2020 concerning Job Creation

\section{The Company's Position as a Legal Entity According to the Laws and Regulations}

Limited Liability Company is a legal entity. This is confirmed in the general provisions of Article 1 of the Limited Liability Company Law Number 40 of 2007, a Limited Liability Company, hereinafter referred to as a Company, is a legal entity that is a capital partnership, established based on an agreement, conducting business activities with authorized capital which is entirely divided into shares and meets the requirements stipulated in this law and its implementing regulations.

According to E. Utrech, a legal entity (rechtpersoon) is a body that according to the law (criteria) becomes a proponent of rights, that is not soulless, or rather that is not human. Legal entity as a social is a real, it is a true fact in legal relations even though it does not have human form or objects made of iron, wood and so on. ${ }^{1}$ According to Meijers, a legal entity includes something that supports rights and obligations. He added that a legal entity is a reality, concrete, real, even though it cannot be touched, is not imaginary, or is a yuridische realiteit (juridical reality). ${ }^{2}$

According to Yahya Harahap, the personal characteristics of the Company as a legal entity include: ${ }^{3}(1)$ The company is treated as a separate and distinct entity from its owner. (2) Can sue and be sued on behalf of the Company itself. (3) The company may acquire, control and transfer its property under its own name. (3) The responsibility of shareholders is limited to the value of their shares. (4) Shareholders do not manage the Company unless they are elected as a member of the Board of Directors. (5) Carry out continuous activities according to the span stipulated in the Articles of Association.

Legal entities consist of 2 (two) types, namely public legal entities and private legal entities. Public legal entity is a legal entity that regulates the relationship between the state and / or its apparatus and citizens in the public / 
public interest. Example: State, Local Government, State institutions such as Bank Indonesia. ${ }^{4}$ In a public legal entity, it can be seen that there is an element of public interest which is handled by the state. ${ }^{5}$ Meanwhile, a private legal entity is an association of people who carry out cooperation and constitute a unit that fulfills the requirements stipulated by law. Private legal entities always aim to seek profit (profit oriented), such as Limited Liability Companies. However, some are not fully profit / material oriented, such as foundations. ${ }^{6}$ In private legal entities, it can be seen that there are elements of individual interests in private bodies. ${ }^{7}$

Legal entities consist of 2 (two) types, namely public legal entities and private legal entities. Public legal entity is a legal entity that regulates the relationship between the state and / or its apparatus and citizens in the public / public interest. Example: State, Local Government, State institutions such as Bank Indonesia. ${ }^{4}$ In a public legal entity, it can be seen that there is an element of public interest which is handled by the state..$^{5}$ Meanwhile, a private legal entity is an association of people who carry out cooperation and constitute a unit that fulfills the requirements stipulated by law. Private legal entities always aim to seek profit (profit oriented), such as Limited Liability Companies. However, some are not fully profit / material oriented, such as foundations. ${ }^{6}$ In private legal entities, it can be seen that there are elements of individual interests in private bodies. ${ }^{7}$

As a comparison in the Netherlands, the legal entity in the Netherlands Burgerlijk Wetboek (NBW) is regulated in book 2 , there is no limit to what is meant by a legal entity. Pursuant to Article 1 paragraph (1) and Article $2 \mathrm{NBW}$, what is meant by public legal entities is the State, province, municipalities (regencies / cities), The Waterboards and other institutions that are authorized in the legislative sector (making and issuing Regulations. Legislation) based on the Dutch Basic Law. Bodies that can also be called public legal entities are entities other than those mentioned in Article 1 which are authorized in the context of Government tasks and the results of Government tasks and the results for which the authority is granted are specifically determined or in accordance with law. Thus, the criteria used to determine a body as a public legal entity is the existence of legislative authority that is owned by that body based on the Dutch Constitution or a body which is certain other bodies that have or are given the authority to carry out Government tasks. ${ }^{8}$

Meanwhile, private legal entities in NBW are regulated in Article 3 Private Legal Persons, which states that "Associations, Corporation and Foundations have Legal personality", entities included as private legal entities are associations / associations, limited liability companies, private insurance companies, Public Limited Company, Closed / Private Limited Companies and Foundations. Thus, the criteria used to determine whether a legal entity is a private legal entity based on the form of that legal entity, these forms of legal entity are legal entities which usually have certain objectives such as seeking profit or social goals having the same status as an individual who does not have the authority. like a public legal entity. ${ }^{9}$

Based on this, LLC is a business entity that is included in a private legal entity because in its activities it carries out business activities and looks for profit. Obtaining the status of a LLC legal entity is followed by the process of establishing a LLC as regulated in the Limited Liability Company Law Number 40 of 2007 which went through the stages of establishment, legal entity ratification, registration and announcement. Thus, it can be seen that the position of a Limited Liability Company (LLC) is a legal entity that can be equated with a legal subject of a person where he can obtain rights and have obligations in carrying out legal actions. The LLC was given the position of "persona standi in judicio". The LLC is given an independent position apart from the individuals in that LLC. The LLC is given the same characteristics as the legal subject in a natural human form. Even though he is not a natural human being, but through the law, he is constructed as a body that can perform legal actions, from which if benefits arise, those profits are considered merely as burdens of the body without involving the individuals. ${ }^{10}$

\section{Position Micro and Small Enterprises Limited Liability Company in terms of Law Number 11 of 2020 concerning Job Creation}

After the issuance of the Job Creation Law Number 11 of 2020, the matters that regulate Micro and Small Enterprises can now be established in the form of a company and are a legal entity. This is confirmed in Article 109 of the Job Creation Law which in that Article amending several provisions stipulated in Law Number 40 of 2007 concerning Limited Liability Companies. One of the amended Articles is the provision of Article 1 paragraph (1) of the Company Law so that it reads: Limited Liability Company, hereinafter referred to as a Company, is a legal entity which is a capital alliance, established based on an agreement, conducting business activities with authorized capital which is entirely divided into shares or a legal entity. individuals who meet the criteria for Micro and SmallEnterprises as stipulated in the statutory regulation concerning Micro and Small Enterprises.

With the amendment of the provisions of Article 1 paragraph (1) of the Company Law by the Job Creation Law, the definition of a Limited Liability Company clearly states that Micro and Small Enterprises Limited Liability Company is an individual legal entity. The Job Creation Act does not provide an explanation of what is meant by Individual Legal Entities. The grammatical meaning of "individual" refers to a person ${ }^{11}$, thus individual refers to one person or individual. So that an Individual Legal Entity is a legal entity that is managed 
by one person. Micro and Small Enterprises Limited Liability Company is an individual business that can be established by 1 (one) person, this provision is regulated in Article 153A of the Job Creation Act, a company that meets the criteria of a Micro and Small Business can be established by 1 (one) person. Then confirmed in Government Regulation Number 8 of 2021 concerning Authorized Capital of Companies and Registration of Establishment, Amendment and Disbanding of Companies that Meet the Criteria for Micro and Small Businesses, Article 2 paragraph (1) states that companies that meet the criteria for micro and small businesses consist of:

a. company established by 2 (two) or more persons, and

b. an individual company established by 1 (one) person.

The latest criteria for Micro and Small Enterprises can be seen in the provisions of Article $35 \mathrm{PP}$ Number 7 of 2021 where Micro, Small and Medium Enterprises are grouped based on the criteria for business capital or annual sales proceeds that will be used for the establishment or registration of business activities. Furthermore, in paragraph (3) Article 35 determines: The criteria for business capital for Micro Enterprises, namely having business capital up to a maximum of Rp. 1,000,000,000.00 (one billion rupiah) excluding land and business premises

The criteria for business capital for small businesses are having a business capital of more than Rp. $1,000,000,000.00$ (one billion rupiah) up to a maximum of Rp. 5,000,000,000.00 (five billion rupiah) excluding land and buildings for business premises.

For the criteria for annual sales results, Article 35 paragraph (5) Government Regulation Number 7 Year 2021 determines: Micro businesses have annual sales results of up to a maximum of Rp. 2,000,000,000.00 (two billion rupiah). Small Businesses have annual sales of more than Rp. 2,000,000,000.00 (two billion rupiah) up to a maximum of Rp. 15,000,000,000.00 (fifteen fifteen rupiahs).

After observing the provisions stipulated in the Job Creation Law regarding Micro and Small Enterprises Limited Liability Company and the implementing regulations, it can be seen that a micro and small business can only be made a LLC and has the position of an individual legal entity if the criteria for micro and small businesses have been explained above. Meanwhile, if these criteria are not met, it cannot be said to be a Limited Liability Company for Micro and Small Business Individuals and must be established based on the terms and conditions stipulated in the Law of LLC.

The Job Creation Law provides specificity for Micro and Small Enterprises Limited Liability Company. This specificity is explained in Article 109 of the Job Creation Law where the Article also changes the provisions of Article 7 paragraph (7) of the Limited Liability Company Law, namely regarding the provisions requiring the Company to be established by 2 (two) persons or more does not apply to: (a) company all of whose shares are owned by the State; (b) Regional Enterprises; (c) Village Enterprises; (d) Companies that manage stock exchanges, clearing and guarantee institutions, depository and settlement institutions, and other institutions in accordance with the Law on Capital Markets; or (e) Companies that meet the criteria for Micro and Small Enterprises.

Micro and Small Enterprises Limited Liability Company as a legal entity provides benefits for micro and small business actors because by forming a LLC and having the status of a legal entity, there is a separation of the assets owned by the Company from the private property of the founder or shareholder, having rights and obligations in carrying out legal actions, as well as the liability of the shareholders is limited to the value of their shares. Thus, by law the Micro and Small Enterprises Limited Liability Company is also given the position of "persona standi in judicio".

Based on the purpose of the creation of the Job Creation Law as referred to in Article 3 of the Job Creation Law, the establishment of Micro and Small Enterprises Limited Liability Company is one of the government's efforts to encourage micro and small individual entrepreneurs to take advantage of the benefits of doing business in the form of a legal entity. Thus, the position of Micro and Small Enterprises Limited Liability Company is as a legal entity even though the founder is only 1 (one) person and can take legal actions on behalf of the Company.

So, the legal position of Micro and Small Enterprises Limited Liability Company as a legal entity is subject to the applicable provisions in the Job Creation Law and Government Regulation Number 8 of 2021 for Micro and Small Enterprises Limited Liability Company established by 1 (one) person and meeting the criteria for Micro and Small Business as referred to in Government Regulation Number 7 of 2021. If a Micro and Small Enterprises Limited Liability Company is established by 2 (two) or more people and meets the criteria for Micro and Small Business, it is subject to the applicable provisions in the Limited Liability Company Law Number 40 of 2008 and / or Micro and Small Enterprises Limited Liability Company established by 1 (one) person (individual company) no longer meets the criteria for Micro and Small Enterprises and is also subject to the applicable provisions in the Company Law. 


\section{B. How to Set Up Micro and Small Enterprises Limited Liability Company according to Indonesian Positive Law}

\section{How to Establish a Limited Liability Company (LLC) in General (according to Law Number 40 of 2007 concerning Limited Liability Companies)}

Based on Article 7 paragraph (1) of Law Number 40 of 2007, in order to establish a Limited Liability Company, the following elements must be fulfilled: ${ }^{12}$

(1) There are two or more persons to establish the Company, (2) There is a statement of intention from the founder for approval to establish the Company by requiring each founder to take of a shares at the time the Company was founded, (3) The agreement of establishment of the Company shall be stated before a notary (notary) in the form of a deed an Indonesian language establishment which also contains the articles of association of the Company. Based on the provisions of this Article, it can be concluded that in establishing a LLC, it must meet several conditions, namely: ${ }^{13}$ 1) Subjective Requirements, namely a minimum of 2 (two) persons, which is meant by persons including legal entities, for example 2 (two) LLCs will establish a new LLC, then this means that they are allowed, because they meet the elements of 2 (two) persons. For the objective requirements, namely the notarial deed and the deed is made in Indonesian.

The agreement for the establishment of a limited liability company requires a notary deed. Notary Deed, hereinafter referred to as Deed, is an authentic deed made by or before a Notary Public according to the form and procedure stipulated in the Law on the Position of Notary Public. In the law of proof, an authentic deed is seen as a binding and perfect evidence. ${ }^{14}$ If that the submitted is not a notarial deed, the application for legalization of the deed of establishment of a Limited Liability Company may be rejected by the Minister of Justice, so that it will result in the Limited Liability Company not being a legal entity.

After making the deed of establishment in front of a notary public, what becomes mandatory next is that the deed of establishment of the LLC is requested for approval from the Minister of Law and Human Rights in order for a LLC to obtain legal entity status

According to Article 10 of the Company Law, an application to obtain a Ministerial Decree concerning the Ratification of a Company Legal Entity must be submitted to the minister no later than 60 (sixty) days as from the date of signing the deed of establishment, which is accompanied by other supporting documents.

Based on the provisions of Article 7 paragraph (4) of the 2007 Company Law, the Company obtained legal entity status on the date of the issuance of the Decree of the Minister of Law and Human Rights regarding the ratification of the Company's legal entity. So that to establish a limited liability company requires the approval of the Minister of Law and Human Rights related to its deed of establishment. If what is submitted is not a notarial deed, the application for legalization of a limited liability company establishment deed may be rejected by the Minister of Law and Human Rights, which results in the Limited Liability Company not having a legal entity. ${ }^{15}$

After the minister has ratified the Limited Liability Company status as a legal entity, based on Article 30 Limited Liability Company Law, the minister shall announce in the Supplement to the State Document of the Republic of Indonesia: (a) The deed of establishment of the Company along with the ministerial decree as referred to in Article 7 paragraph (4); (b) The deed of amendment to the Company's articles of association along with the ministerial decree as referred to in Article 21 paragraph (1); (c) The deed of amendment to the articles of association which notification has been received by the Minister.

In the limitation or definition of LLC as described in Article 1 point 1 of Company Law, it is clearly stated that LLC is the Capital Alliance which is divided into shares. So the emphasis here is capital. In other words, talking about Limited Liability Company means talking about capital. Therefore, it is true that a LLC is called a pool of capital. For this reason, it is not excessive if the capital in the LLC is used as a material condition in the establishment of LLC. This means that if you want to establish a LLC, there must be capital. Capital in LLC consists of 3 types, namely: ${ }^{16}$ (a) Authorized Capital or often referred to as statutory capital, namely the amount of capital stated in the Articles of Association of Limited Liability Companies. Article 32 of the Company Law states that the authorized capital of the Company is at least Rp. 50,000,000.00 (fifty million rupiah), but with the issuance of Government Regulation Number 29 of 2016 concerning Changes in the Authorized Capital of Limited Liability Companies, which is based on the provisions of Article 1 that the amount of the Company's capital is determined by the founders of the Company; (b) Issued or subscribed capital, namely a portion of the company's capital has been approved to be subscribed by the founders, in the form of shares. Precisely in Article 33 of the Company Law paragraph (1) it is stated that at least $25 \%$ (twenty five percent) of the authorized capital as referred to in Article 32 must be issued and fully paid. (c) Paid-in Capital is capital that actually already exists in the company's treasury. This capital is paid up by the shareholders. All shares that have been issued must be paid up in full at the time of company approval with valid proof of payment. However, with the issuance of Government Regulation Number 29 of 2016 concerning Changes in the Authorized Capital of Limited Liability Companies, which is based on the provisions of Article 
1 that the amount of the Company's capital is determined by the founders of the Company.

\section{How to set up Micro and Small Enterprises Limited Liability Company according to Law Number 11 of 2020 concerning Job Creation}

The establishment of Micro and Small Enterprises Limited Liability Company is stipulated in Article 153A paragraph (1) of the Job Creation Law, namely companies that meet the criteria for Micro and Small Businesses can be established by 1 (one) person. In Government Regulation Number 8 of 2021 concerning the Authorized Capital of Companies and Registration of Establishment, Amendment and Disbanding of Companies that Meet the Criteria for Micro and Small Businesses to classify Companies for Micro and Small Enterprises into 2 types, which can be found in the sound of Article 2 paragraph (1) which reads: Companies that meet the criteria for micro and small businesses consist of: (a) Companies established by 2 (two) or more persons; and (b) an individual company established by 1 (one) person.

Furthermore, in paragraph (2) the Article determines that the establishment, amendments to the articles of association, and dissolution of the Company as referred to in paragraph (1) letter a shall be implemented in accordance with the provisions of the laws and regulations concerning Companies. This means that Micro and Small Enterprises Limited Liability Company established by 2 (two) or more people must follow the principles stipulated in the Limited Liability Company Law Number 40 of 2007 . As for established by 1 ( one) person follows the principles or provisions of the Job Creation Law and Government Regulation Number 8 of 2021.The requirements that must be met for Limited Liability Company for Micro and Small Business Individual according to Government Regulation Number 8 of 2021 are: (a) Minimum age 17 (seventeen years; and (b) legal competence.

The amount of the Company's own capital is regulated in Article 32 of LLC Law Number 40 of 2007, where the company's authorized capital is at least Rp. 50,000,000.00 (five million rupiah). However, with the issuance of Government Regulation Number 29 of 2016 concerning Changes in the Authorized Capital of Limited Liability Companies, which is based on the provisions of Article 1 that the total capital of the Company determined by the founders of the Company. The provisions regarding the amount of company capital have also been amended by the Job Creation Law Number 11 of 2020 in Article 109 which changes the provisions of Article 32 of Law Number 40 of 2007 concerning Limited Liability Companies so that the amount of authorized capital of the Company as referred to in paragraph (1) is determined based on decision of the founder of the Company.

According to Article 4 of Government Regulation Number 8 of 2021, the authorized capital of the Company for Micro and Small Enterprises must be issued and fully paid at least $25 \%$ (twenty five percent) as evidenced by valid proof of payment. The valid proof of payment must be submitted electronically to the Minister within 60 (sixty) days from the date of the Company's deed of establishment for the Company; or filling out a Statement of Establishment for an Individual Company.

Furthermore, Article 153A paragraph (2) of the Limited Liability Companion Law stipulates that the establishment of a Micro and Small Enterprises Limited Liability Company is based on a statement of establishment made in Indonesian. This means that the establishment of this Limited Liability Company does not require a deed of establishment drawn up by or in front of a notary. According to Government Regulation Number 8 of 2021, what is meant by Statement of Establishment according to Government Regulation Number 8 of 2021 is the format for the establishment of an individual Company established by 1 (one) person electronically.

For the status of a Micro and Small Enterprises Limited Liability Company established by 1 (one) person or an Individual Company according to Government Regulation Number 8 of 2021, it is obtained after being registered with the Minister and obtaining an electronic registration certificate (Article 6 paragraph (3)). After obtaining the status of a legal entity, the Individual Limited Liability Company for Micro and Small Enterprises was announced by the Minister on the official website of the directorate general which carries out tasks and functions in the field of general law administration. As for the Limited Liability Company, which is regulated in the Limited Liability Company Law, the announcement is in the Supplement to the State Gazette of the Republic of Indonesia.

According to Article 9 of Government Regulation Number 8 Year 2021, the Individual Limited Liability Company for Micro and Small Enterprises must change their legal entity status to become a Company if the shareholder becomes more than 1 (one) person; and / or do not meet the criteria for micro and small businesses as stipulated in the statutory provisions concerning micro and small enterprises. In the event that an Individual Limited Liability Company, prior to becoming a Company, must change its status through a notary deed and be registered electronically with the Minister and the change in status is carried out in accordance with the statutory provisions concerning the Company.

Law Number 11 of 2020 concerning Work Liability Compensation regarding Micro and Small Enterprises Limited Liability Companies has indeed been clearly regulated in Article 109 to Article 153J which 
is then further regulated by Government Regulation Number 8 of 2021. Some of the provisions that are still not appropriate, namely as the conditions of establishment stipulated in the Employment Liability Companion Law and Government Regulation Number 8 of 2021 as determined by the Limited Liability Company Law Number 40 of 2007, which creates uncertainty because as stated by Kelsen, the rules contained in a law the nature must be clear and must not be contradictory.

Based on the hierarchy of laws and regulations between the Limited Liability Companion Law Number 11 of 2020 and the Limited Liability Company Law Number 40 of 2007, it is a horizontal conflict of norms. The issue is which laws must be followed by a Micro and Small Enterprises Limited Liability Company? The Limited Liability Company Law only makes changes or adjustments to some of the provisions set out in the Limited Liability Company Law, meaning that these changes do not necessarily invalidate the law. The Limited Liability Company Law remains the lex specialist law for Limited Liability Companies. Micro and Small Enterprises Limited Liability Company also applies Limited Liability Company Law if in its establishment it is carried out by 2 (two) or more people and is not an Individual Limited Liability Company. As for the Limited Liability Company for Individuals, Micro and Small Enterprises, it applies to the Limited Liability Company Law Number 11 of 2020 and Government Regulation Number 8 of 2021 as lex imperiori law, namely the new law that overrides the old law. Form of Legal Liability of the Founder Micro and Small Enterprises Limited Liability Company According to the Prevailing Laws.

\section{Legal Liability of the Company Founders According to Law Number 40 of 2007 concerning Limited Liability Companies}

In accordance with legal principles, in principle, the founders and the Board of Directors as long as the Company has not been approved as a legal entity, is in and stands in a "reliable position" (stand in fiduciary position) against the Company. Therefore, they are fully responsible personally (personal liability) for all legal actions they take with third parties. This is also emphasized in Article 3 paragraph (2) letter a Limited Liability Company Law 2007, that legal actions taken before the Company is legal as a legal entity are the responsibility of the person who commit. ${ }^{17}$ The extent to which the founders' responsibility for their legal actions before the Company is certified as a legal entity has been regulated in the Limited Liability Company Law 2007, as will be explained below. ${ }^{18}$

If the legal action is carried out on behalf of the Company by all members of the Board of Directors together with all founders and all members of the Board of Commissioners, even though when the legal action is carried out the Company is not yet a legal entity, the responsibility is first, in principle it becomes joint responsibility (hoofdelijken gezameljk aanspraakelijk, jointly and severally liable) for the legal act. This joint responsibility becomes the responsibility of the Company after the Company becomes a legal entity.

The second classification that commits legal actions on behalf of the Company is only the founders and at the time the legal actions were carried out the Company had not yet obtained the status of a legal entity. In such a case, the legal act becomes the personal responsibility of the founder concerned, and the legal act is not binding on the Company. ${ }^{19}$ Regarding this, it is emphasized again in the Elucidation of Article 14 paragraph (2) Limited Liability Company Law 2007. What is meant by the founder's responsibility which is not binding on the Company is the responsibility of the founder who commits the act personally, the Company is not responsible for any legal actions that done that founder.

The position of the founders and their responsibilities after the Company has been ratified as a legal entity. Referring to Article 7 paragraph (2) Limited Liability Company Law 2007, the position of the founder at the time the Company was founded was none other than the shareholder, and if this is linked to Article 3 paragraph (1) which reads: ${ }^{20}$

"The shareholders of the Company are not personally responsible for the engagement made on behalf of the Company and are not responsible for the company's losses exceeding the value of the shares they have subscribed for"

After being legalized by the Company to become a Legal Entity, the responsibility for all legal actions is transferred to the Limited Liability Company with the principle of limited liability. The definition of limited liability or limited liability in this case relates to the occurrence of a debt or losses. The debt will be paid sufficiently from the assets available in the Limited Liability Company. on the other hand, those who invest in a Limited Liability Company or shareholder, for sure, will not bear the debt loss more than the share of their assets that are embedded in the Limited Liability Company. ${ }^{21}$

In fact, the doctrine of limited liability of a legal entity means that for every action that is carried out by a legal entity, the only person responsible is the legal entity itself. Shareholders are not responsible except for the value of the shares they include. As a separate legal personality, the principle of separation of powers has created limited liability from shareholders, managers and supervisors. Limited liability means that shareholders are only responsible for the value of the shares they own, not including their personal assets. 


\section{Legal Liability of Micro and Small Enterprises Limited Liability Company Founders according to the Laws and Regulations}

Regarding the legal liability of the founders for legal actions before the Company is ratified as a legal entity. The principle of "stand fiduciary position" also applies to Limited Liability Companies for Micro and Small Businesses where the founder is fully responsible personally for all legal actions that will be carried out. This is also emphasized in Article 153J paragraph (2) of the Limited Liability Companya Law, namely that the responsibility of shareholders becomes unlimited or becomes personal responsibility if the requirements of the Company as a legal entity have not been fulfilled or have not been fulfilled. Joint ownership also applies to Micro and Small Enterprises Limited Liability Companies in the event that there are 2 (two) founders or more. Based on Pitlo's opinion regarding free joint ownership, the founders are free to control or transfer their rights over the joint ownership. This means that as long as the Micro and Small Enterprises Limited Liability Company has not been legalized as a legal entity, joint ownership in effect is free joint ownership not binding joint ownership.

If it has become a legal entity, what applies is binding joint ownership. It is different when a Micro and Small Enterprises Limited Liability Company was founded by 1 (one) person, then of course there is no such thing as joint ownership because no other founder puts his assets or shares into the company or the Limited Liability Company (inbreng). In the event that the founder wants to control or transfer his rights over the assets entered into the company, the founder is free to control or transfer his property or property, whether the Limited Liability Company is legal as a legal entity or not yet legalized as a legal entity. Regarding legal actions taken by all members of the board of directors together with all founders and all boards of commissioners on behalf of the Company before being legalized as a legal entity, according to Article 14 Limited Liability Company Law 2007 which applies a joint responsibility. This also applies to Micro and Small Enterprises Limited Liability Companies even though it is not explicitly stated in the Limited Liability Companion Act, because the Limited Liability Companion Law does not revoke the Limited Liability Company Law Number 40 of 2008 but only holds amendments to certain articles of the Limited Liability Company Act. So that all provisions that are not regulated either in the Work Limited Liability Companion Act or Government Regulation Number 8 of 2021 apply to all the provisions contained in the Limited Liability Company Law.

After the Micro and Small Enterprises Limited Liability Company was legalized as a legal entity, the form of responsibility for the founder of the Limited Liability Company is the same as that of the founders of the Company in general, namely limited liability.

The responsibility of the founders of Micro and Small Business Companies as legal entities is affirmed in Article 153J paragraph (1) of the Limited Liability Company Law Number 11 of 2020, the shareholders of the Company for Micro and Small Enterprises are not personally responsible for the engagement made on behalf of the Company. exceeds the shares held. Thus, the principle of limited liability is also attached to Micro and Small Enterprises Limited Liability Companies even though there is only one shareholder.

Based on Article 153J paragraph (2) the principle of limited liability becomes invalid if the founders or shareholders concerned, either directly or indirectly in bad faith, use the Company for personal gain, the shareholders are also involved or participate in illegal acts committed by the Company. as well as shareholders, either directly or indirectly, illegally using the Company's assets, which results in the Company's assets being insufficient to pay off the Company's debts. Thus, if the founder or shareholder commits one of these acts, he must be personally responsible for all legal consequences for the act he has committed to use his personal assets to pay off all debts of the Company.

As a theory of responsibility in the sense of liability where all the characters of risk or definite responsibility, which depend or may include all characters of actual or potential rights and obligations such as losses, threats, crimes, costs or conditions that imply the Limited Liability Company has the duty to carry out the law law or in other words due to errors committed by legal subjects. Thus, if the losses are caused by the activities of the Company, this liability shall be borne by the Company itself. However, if the loss is caused by an unlawful act, whether committed by the shareholders or management of the Company, then the personal responsibility is borne by those who commit acts against the law or things that harm the Company.

\section{CONCLUSION}

1. The status of Micro and Small Enterprises Limited Liability Companies in terms of Law Number 11 of 2020 concerning Limited Liability Company Work. Micro and Small Enterprises Limited Liability Company is an individual legal entity, where this Limited Liability Company must meet the criteria for micro and small businesses as stipulated in Government Regulation Number 7 of 2021 concerning Ease, Protection and Empowerment of Cooperatives and Micro, Small and Medium Enterprises. The Micro and Small Enterprises Limited Liability Company according to Government Regulation Number 8 of 2021 concerning the Authorized 
Capital of the Company and the Registration of the Establishment, Amendment and Disbursement of Companies that meet the Criteria for Micro and Small Businesses are classified into 2 (two) types, namely Companies established by 2 ( two) or more people (the Company) and an Individual Company established by 1 (one) person (Limited Liability Company Individual).

2. How to establish a Micro and Small Enterprises Limited Liability Company according to Indonesian positive law. Limited Liability Companies for Individual Micro and Small Businesses are established based on the provisions of Law Number 11 of 2020 concerning Work Liability Companion and Government Regulation Number 8 of 2021 concerning the Company's Authorized Capital and Registration of Establishment, Amendment and Disbanding of Companies that Meet the Criteria for Micro Business and Small. Meanwhile, companies are established based on the provisions of Law Number 40 of 2008 concerning Limited Liability Companies.

3. The form of responsibility for the founders of Micro and Small Enterprises Limited Liability Company according to the laws and regulations. Micro and Small Enterprises Limited Liability Company, the responsibility of the founder for legal actions before the Company is legalized as a legal entity is responsible personally against his legal actions. After the Micro and Small Enterprises Limited Liability Company has been legalized as a legal entity, the legal responsibility of the founder as described in Article 153J of Law Number 11 of 2020 concerning Limited Liability Compensation for Work, the principle of limited liability is also attached to Micro and Small Enterprises Limited Liability Companies the same as Limited Liability Company in general although Micro and Small Enterprises Limited Liability Company has one founder or one shareholder.

\section{REFERENCES}

Agus Budiarto, Kedudukan Hukum dan Tanggung Jawab Perseroan Terbatas, Bogor:Ghalia Indonesia, cet. 2, 2009.

Azizah, Hukum Perseroan Terbatas, Malang: Anggota IKAPI, 2016.

C.S.T. Kansil \& Christine S.T. Kansil, Pokok-Pokok Perseroan Terbatas Tahun 1995, Jakarta: Pustaka Sinar Harapan, cet. 2, 1997.

Kurniawan, Hukum Perusahaan, Karakteristik Badan Usaha Berbadan Hukum danTidak Berbadan Hukum di Indonesia, Yogyakarta: Genta Publishing, 2014

Mulhadi, Hukum Perusahaan, Bentuk-Bentuk Badan Usaha di Indonesia, Depok:Rajawali Pers, Ed. 1, Cet. 3, 2020.

M. Yahya Harahap, Hukum Perseroan Terbatas, Jakarta: Sinar Grafika, cet. 4, 2013.Neni Sri Imaniyati dan Panji Adam Agus Putra, Hukum Bisnis, Dilengkapi Dengan Kajian Hukum Bisnis Syariah, Bandung: Limited Liability Company Refika Aditama, 2017.

Rudhi Prasetya, Teori dan Praktik Perseroan Terbatas, Jakarta: Sinar Grafika, cet. 1,2011.

Sentosa Sembiring, Hukum Perusahaan tentang Perseroan Terbatas, Bandung:Nuansa Aulia, 2012.

A.A. Gede D.H. Santoso, Perbedaan Badan Hukum Publik dan Badan Hukum Privat,Jurnal Hukum Universitas Udayana, 2019, hlm. 164, http//ejournal.undikhsa.ac.id/index. Diakses pada tanggal 5 Februari 2021, pukul 15:27 WITA.

Verti Tri Wahyuni, Kepemilikan Tunggal Badan Hukum Perseroan Terbatas (Limited Liability Company), Jurnal Hukum Magister Hukum Universitas Gadjah Mada, 2 Agustus 2017.Hlm. 208

Http://journal.uad.ac.id/index.php/Novelty/article. Diakses pada tanggal 7 Maret 2021, pukul 15:15 WITA.

Indonesia, Undang-Undang Nomor 40 Tahun 2007 tentang Perseroan Terbatas(Lembaran Negara Republik Indonesia Tahun 1995 Nomor 13,Tambahan Lembaran Negara Republik Indonesia Nomor 3587).

Indonesia, Undang-Undang Nomor 20 Tahun 2008 tentang Usaha Mikro, Kecil, dan Menengah (Lembaran Negara Republik Indonesia Tahun 2008 Nomor93, Tambahan Lembaran Negara Republik Indonesia Nomor 4866).

Indonesia, Undang-Undang Nomor 11 Tahun 2020 tentang CiLimited Liability Companya Kerja(Lembaran Negara Republik Indonesia Tahun 2020 Nomor 245, Tambahan Lembaran Negara Republik Indonesia Nomor 6573). 
Indonesia, Peraturan Pemerintah Republik Indonesia Nomor 29 Tahun 2016tentang Perubahan Modal Dasar Perseroan Terbatas.

Indonesia, Peraturan Pemerintah Republik Indonesia Nomor 8 Tahun 2021 tentang Modal Dasar Perseroan Serta Pendaftaran Pendirian, Perubahan, dan Pembubaran Perseroan yang Memenuhi Kriteria Usaha Mikro dan Kecil.

https://www.google.com/amp/s/kbbi.web.id/perorangan.html. Diakses pada tanggal 6April 2021, pukul 21:25 WITA 